\title{
Natural sparkling guava wine: volatile and physicochemical characterization
}

\author{
Silvana Maria Michelin Bertagnolli ${ }^{1 *}$ Gabrieli Bernardi ${ }^{2}$ Jossiê Zamperetti Donadel $^{1}$ \\ Aline de Oliveira Fogaça ${ }^{3}$ Roger Wagner $^{4}$ Neidi Garcia Penna ${ }^{4}$
}

\begin{abstract}
'Programa de Pós-graduação em Ciência e Tecnologia dos Alimentos (PPGCTA), Centro de Ciências Rurais (CCR), Universidade Federal de Santa Maria (UFSM), 97050-790, Santa Maria, RS, Brasil. E-mail: silvibert@yahoo.com.br. *Corresponding author.

${ }^{2}$ Departamento de Engenharia e Tecnologia Ambiental, Universidade Federal de Santa Maria (UFSM), Campus Frederico Westphalen, Frederico Westphalen, RS, Brasil.

${ }^{3}$ Curso de Farmácia, Centro Universitário Franciscano (Unifra), Santa Maria, RS, Brasil.

${ }^{4}$ Departamento de Tecnologia e Ciência dos Alimentos (DTCA), Centro de Ciências Rurais (CCR), Universidade Federal de Santa Maria (UFSM), Santa Maria, RS, Brasil.
\end{abstract}

\begin{abstract}
Although different tropical fruit species have been used in the development of fermented beverages, there are only few references in the literature to the production of natural sparkling wines from fruits other than grapes. In this sense, the objective of the present research was the development and physicochemical and volatile characterization of a natural sparkling guava wine produced by the champenoise method. Volatile compounds were identified by gas chromatography coupled to mass spectrometry using the headspace solid-phase microextraction (HS-SPME) technique on samples. Eighty-nine volatile compounds were detected, of which 51 were identified. Esters were the predominant class of volatile compounds (a total of 26), followed by alcohols (10), terpenes (9), ketones (3), and acids (3). Volatile compounds with possible odoriferous activity were reported in the beverage, including ethyl octanoate, ethyl 5-hexenoate, phenethyl acetate, (E)- $\beta$-damascenone, (E)-ethyl cinnamate, 2-methyl butyl acetate, 3-methylbutanol, ethyl 3-(E)-hexenoate, and methyl 5-hexenoate. Natural sparkling guava wine produced showed a complex composition of fruity and floral aromas. Furthermore, the use of the champenoise method, traditionally applied to grapes, enabled the manufacture of a natural sparkling guava wine with physicochemical characteristics equivalent to those of sparkling wines made from grapes.
\end{abstract}

Key words: fermentation, Psidium guajava L., volatile compounds, gas chromatography.

Espumante natural de goiaba: caracterização volátil e físico-química

RESUMO: Diferentes frutos tropicais vêm sendo utilizados para o desenvolvimento de bebidas fermentadas, porém na bibliografia consultada há poucas referências sobre a produção de espumantes naturais de outras frutas diferentes da uva. Nesta perspectiva, o objetivo deste trabalho foi o desenvolvimento e a caracterização fisico-química e volátil de um espumante natural de goiaba produzido pelo método champenoise. A determinação dos compostos voláteis foi realizada por cromatografia em fase gasosa acoplada a espectrometria de massas utilizando a técnica de microextração em fase sólida no headspace (HS-SPME) das amostras. Foram detectados 89 compostos voláteis, dos quais 51 foram identificados. Os ésteres foram os compostos voláteis predominantes em número, totalizando 26 compostos, seguido pelos álcoois (10), terpenos (9), cetonas (3) e ácidos (3). Compostos voláteis com possivel atividade odorifera foram encontrados na bebida, dentre eles os ésteres octanoato de etila, 5-hexenoato de etila, acetato de fenetila, (E)- $\beta$-damascenona, (E)-cinamato de etila, acetato de 2-metil butila, 3-metil butanol, 3-(E)-hexenoato de etila e o 5-hexenoato de metila. O espumante natural produzido apresentou uma composição complexa de aroma frutado e floral. Além disso, a utilização do método tradicionalmente aplicado a uvas, o champenoise, proporcionou a fabricação de um espumante natural de goiaba com características fisico-químicas equivalentes aos espumantes elaborados a partir de vinho.

Palavras-chave: fermentação, Psidium guajava L., compostos voláteis, cromatografia em fase gasosa.

\section{INTRODUCTION}

The guava tree (Psidium guajava L.) is a fruit tree belonging to the Myrtaceae family that is indigenous to tropical regions of Central and South America (LIMA et al., 2010). Guava fruit has a high nutritional value and sensorial acceptance, and it is consumed both fresh and in processed forms. Fruit processing minimizes post-harvest losses by obtaining products with a longer shelf-life and high added value. An alternative to reduce such losses and improve fruit utilization consist of the production of 
fermented fruit beverages, which consumer surveys indicate to be promising products due to their acceptance (SANDHU \& JOSHI, 1995).

Commercialization of sparkling wine has had a considerable evolution in Brazil, as represented by the increase in consumption influenced by the warm Brazilian climate as well as the pleasant flavors and aromas of these beverages. Thus, the use of fruit species other than grapes could pose a good alternative for the production of this type of beverage. Champagne, sparkling, or natural sparkling are types of wine whose carbonic anhydrides come exclusively from a second alcoholic fermentation step, whether in bottles (champenoise/traditional method) or in large containers (Chaussepied/Charmat method), with a minimum pressure of 4 atmospheres at $20^{\circ} \mathrm{C}$ and an alcohol content of $10 \%$ to $13 \%$ by volume (BRASIL, 2004). During this second fermentation step, the sparkling wine develops characteristic flavor compounds (TORRESI et al., 2011). Yeast autolysis also occurs during this period, yielding the release of intracellular compounds such as amino acids, peptides, proteins, polysaccharides, nucleic acid derivatives, and lipids. These compounds are precursors to many volatile compounds, such as vitispirane and diethyl succinate, that contribute positively to the quality of sparkling wines (BOSCH-FUSTÉ et al., 2007). The volatile fraction of fermented fruits is very complex, consisting of compounds with different physicochemical properties (polarity, volatility, and solubility) and a wide range of concentrations (ETIEVANT \& MAARSE, 1991).

Volatile compounds that are formed in this process are characterized as the tertiary aromas of the sparkling wine. While the primary aromas arise from the fruit and are reported in younger products, secondary aromas are formed primarily during the first fermentation (UBIGLI, 2004). SOARES et al. (2007) identified the esters 3(Z)-hexenyl acetate and 3(E)-hexenyl acetate as well as the sesquiterpenes caryophyllene, $\alpha$-humulene, and $\beta$-bisabolene in ripe guava fruit. Conversely, the study by PINO \& QUERIS (2011) on the characterization of guava wine described twelve active odor compounds, including $\beta$-damascenone, ethyl octanoate, ethyl hexanoate, and ethyl butanoate.

Several analytical techniques are employed for the extraction of volatile compounds. Among them, solid-phase microextraction (SPME) has been employed for the isolation of volatile compounds from foods, including alcoholic beverages. This technique has the advantage of being faster and easier to perform than solvent extraction and distillation; it also has good reproducibility and sensitivity (PINO \& QUERIS, 2010). Although, published studies exist on the production and characterization of fermented fruit products, the literature is lacking in studies about volatile compounds in natural sparkling fruit wines (such as guava) and their acceptance by consumers. Thus, the objective of the present research was the development and physicochemical and volatile characterization of a natural sparkling guava wine produced by the champenoise method.

\section{MATERIALS AND METHODS}

\section{Preparation of natural sparkling guava wine}

Ripe guavas of the Paluma variety were purchased from the Polytechnic College of the Universidade Federal de Santa Maria in the municipality of Santa Maria, Rio Grande do Sul State (RS). The guavas were washed under running water and sanitized with a $200 \mathrm{mg} \mathrm{L}^{-1}$ sodium hypochlorite solution (Quimea ${ }^{\circledR}$, Santa Maria, RS, Brazil) for $15 \mathrm{~min}$. The fruit was subsequently cut in half, with the manual removal of skin and seeds. Pulp was reserved for processing.

The must was obtained from pulp homogenized in a blender (Britânia ${ }^{\circledR}$, São Paulo, São Paulo state (SP), Brazil). Pectinolytic enzymes (LAFAZYM enzyme system, Laffort ${ }^{\circledR}$, Bordeaux, France; $0.02 \mathrm{~g} \mathrm{~L}^{-1}$ ) and sulfur dioxide (Veronese, Caxias do Sul, RS, Brazil; 10mg L-1) were added to the must. Sucrose (União, São Paulo, SP, Brazil; $243 \mathrm{~g} \mathrm{~L}^{-1}$ ) was added until the must reached $16.2^{\circ}$ Brix. Fermentation was conducted in $5 \mathrm{~L}$ containers and initiated with the addition of commercial yeast (Saccharomyces cerevisiae, Laffort ${ }^{\circledR}$, Bordeaux, France; $\left.0.2 \mathrm{~g} \mathrm{~L}^{-1}\right)$. At the end of the alcoholic fermentation, the fermented base product was transferred and bottled for the production of the sparkling wine, following the method described by ZOECKLEIN (2002). The fermented base was extracted from the bottles, followed by the addition of sucrose (União, São Paulo, SP, Brazil; 24g L $\mathrm{g}^{-1}$ ) and yeast (Saccharomyces cerevisiae, Laffort $^{\circledR}$, Bordeaux, France). A bentonite- and silicon dioxide-based coadjuvant $\left(\right.$ Pentagel $^{\circledR}$, Diepoldsau, Switzerland; $\left.0.10 \mathrm{~g} \mathrm{~L}^{-1}\right)$ and an ammonium sulfate- and thiaminebased fermentation activator (Thiazote, Laffort ${ }^{\circledR}$, Bordeaux, France; $0.10 \mathrm{~g} \mathrm{~L}^{-1}$ ) were subsequently added. The product was bottled again and capped with a polyethylene plug. The remuage was performed for a period of three months, followed by dégorgement and sealing with a cork stopper and wire protection. Sparkling wine was stored for two months. The entire 
process was carried out at $20-25^{\circ} \mathrm{C}$ on the premises of a commercial winery (Velho Amâncio, Santa Maria, $\mathrm{RS}$, Brazil). Cleaning was carried out at $5^{\circ} \mathrm{C}$. All experiments were performed in triplicate.

\section{Physicochemical analysis}

Natural sparkling guava wine was analyzed for some of its physicochemical parameters. The $\mathrm{pH}$ was determined by direct reading of the sample using a $\mathrm{pH}$ potentiometer $\left(\right.$ Digimed $^{\circledR}$, DM-22, Campo Grande, SP, Brazil). Total acidity was determined using titration by neutralization up to a $\mathrm{pH}$ of 8.2 and is expressed as $\mathrm{mEq} \mathrm{L}^{-1}$ of tartaric acid. Meanwhile, the volatile acidity was determined by steam distillation followed by titration and is expressed in $\mathrm{mEq} \mathrm{L}^{-1}$ of acetic acid. Alcoholic strength was determined by Gibertini ${ }^{\circledR}$ distillation (Gibertini, Italy) according to AMERINE \& OUGH (1980). Reducing sugar content was determined according to Lane and Eynon's method (ZOECKLEIN, 2002). All analyses were performed in triplicate.

\section{Determination of volatile compounds}

Analysis of volatile compounds was carried out using the headspace solid-phase microextraction technique. DVB/Car/PDMS fibers (Supelco ${ }^{\circledR}$, SigmaAldrich, Saint Louis, Missouri, USA; 50/30 $\mu$, $2 \mathrm{~cm}$ long) were used in the procedure. Two hundred milliliters of sample was degassed in an ultrasound bath (Unique ${ }^{\circledR}$, USC-800, Indaiatuba, SP, Brazil) at $2^{\circ} \mathrm{C}$ for $40 \mathrm{~min}$. Sample aliquots of $10 \mathrm{~mL}$ containing $3 \mathrm{~g}$ of sodium chloride (Merck ${ }^{\circledR}$, Darmstadt, Germany) were packed in $20 \mathrm{~mL}$ vials and immediately sealed with a screw cap containing a polytetrafluoroethylene (PTFE) septum. Volatile compound extraction was carried out at $35^{\circ} \mathrm{C}$ with $50 \mathrm{~min}$ of fiber exposure to the sample headspace. The vial containing the sample was maintained for $5 \mathrm{~min}$ under the same conditions prior to the extraction. Sample was stirred throughout the entire analysis period. Extractions were performed in triplicate.

Determination of volatile compounds was performed using a Shimadzu QP-2010Plus gas chromatograph coupled to a mass spectrometer (GC/MS). The SPME fiber containing the isolate was thermally desorbed in the GC/MS injector at a temperature of $250^{\circ} \mathrm{C}$ for $2 \mathrm{~min}$ in the splitless mode. The separation of volatile compounds occurred on a capillary column consisting of fused silica coated with a ZB-5MS non-polar stationary phase $(30 \mathrm{~m} \times$ $0.25 \mathrm{~mm} \times 0.25 \mu \mathrm{m}$; Phenomenex, USA). Temperature program of the column started with 2 minutes at $35^{\circ} \mathrm{C}$, followed by a $4^{\circ} \mathrm{C} / \mathrm{min}$ temperature ramp until reaching $80^{\circ} \mathrm{C}$ and then one other temperature

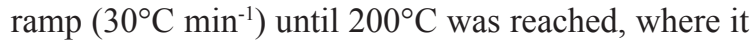
remained in isothermal conditions for $5 \mathrm{~min}$. Helium (purity grade 5.0; White Martins, Osasco, SP, Brazil) was used as a carrier gas with a constant flow rate of $1.2 \mathrm{~mL} \mathrm{~min}^{-1}$. The GC/MS interface and the ionization source were maintained at $250^{\circ} \mathrm{C}$. Quadrupole mass analyzer was operated in the sweep mode $(35-350 \mathrm{~m}$ $\left.z^{-1}\right)$. Volatile compound quantification was performed through internal standardization by adding the internal standard 3-octanol (Sigma Aldrich, $10 \mu \mathrm{L}$ of an ethanol solution at $82.2 \mathrm{mg} \mathrm{L}^{-1}$ ) to the sample according to BERNARDI et al. (2014). Volatile compounds were identified by comparing analyte mass spectra with those in the NIST 05 spectral library and the experimental retention index (RI) of the analyte with the theoretical RI reported in the literature (NIST, El-Sayed, 2014). Experimental RIs were calculated from the retention times of a homologous series of alkanes (C8-C22) obtained under the same chromatographic conditions of the sample. Ethyl acetate, ethyl hexanoate, ethyl octanoate, 2-methyl1-butanol, 3-methyl-1-butanol, 1-hexanol, 1-octanol, phenylethyl alcohol, and hexanoic acid were positively identified by comparing the spectra and chromatographic peak RIs of samples and analytical standards. Odor thresholds of the volatile compounds identified in natural sparkling guava wine were estimated by comparison to values reported from the literature, shown in table 1 , according to PINO \& QUERIS (2011).

\section{RESULTS AND DISCUSSION}

Physicochemical composition of natural sparkling guava wine

Few studies in the literature have employed fruits other than grapes in the production of natural sparkling wines (JIANQIANG et al., 2008; CARVALHO, 2009). Thus, the present results were discussed based on standards used for sparkling wines according to Law 10970 of 2004 that dictates the standards and quality for wine and the derivatives of grapes and wine (BRASIL, 2004).

The natural sparkling guava wine had a $\mathrm{pH}$ of $3.6 \pm 0.2$. A value below 4.0 makes this product less susceptible to acetic bacteria action, which could deteriorate the product (LOPES \& SILVA, 2006). Results of the total and volatile acidity were $114.1 \pm 1.7$ and $13.1 \pm 0.6 \mathrm{mEq} \mathrm{L}^{-1}$ of tartaric acid and acetic acid, respectively. Alcohol content was reported to be $12.0 \pm 0.30 \%$ by volume at $20^{\circ} \mathrm{C}$. Results allowed classification of the natural sparkling 
Table 1 - Volatile compounds identified in natural sparkling guava wine.

\begin{tabular}{|c|c|c|c|c|c|c|c|}
\hline Class & No. & Compounds & $\mathrm{ID}^{\mathrm{a}}$ & $\mathrm{RI}_{\text {Exp }}$ & $(\mu \mathrm{g} / \mathrm{L})$ & SD & Odor threshold $^{\mathrm{b}}\left(\mu \mathrm{g} \mathrm{L}^{-1}\right)$ \\
\hline \multirow{28}{*}{ Esters } & 1 & Ethyl isobutyrate & $\mathrm{b}$ & 705 & 63.40 & 5.10 & - \\
\hline & 2 & Isobutyl acetate & $\mathrm{b}$ & 744 & 14.60 & 9.02 & 66.0 \\
\hline & 3 & Ethyl lactate & $\mathrm{b}$ & 814 & 18.20 & 4.26 & 1400.0 \\
\hline & 4 & Isopentyl acetate & $\mathrm{b}$ & 881 & 335.00 & 8.30 & - \\
\hline & 5 & 2-Methylbutyl acetate & $\mathrm{b}$ & 883 & 60.20 & 2.37 & 30.0 \\
\hline & 6 & Methyl hexanoate & $\mathrm{b}$ & 927 & 2.80 & 0.27 & - \\
\hline & 7 & Ethyl hexanoate & $\mathrm{a}$ & 1003 & 396.00 & 5.26 & 30.0 \\
\hline & 8 & 3(E)-ethyl hexenoate & $\mathrm{a}$ & 1009 & 176.00 & 4.17 & 14.0 \\
\hline & 9 & Hexyl acetate & $\mathrm{b}$ & 1016 & 106.30 & 3.00 & - \\
\hline & 10 & 5-Methyl hexenoate & $\mathrm{b}$ & 1018 & 7.30 & 1.54 & 2.0 \\
\hline & 11 & 2(E)-ethyl hexenoate & $\mathrm{b}$ & 1045 & 3.90 & 0.11 & - \\
\hline & 12 & 2-Ethyl furoate & $\mathrm{b}$ & 1053 & 11.20 & 0.26 & - \\
\hline & 13 & Methyl octanoate & $\mathrm{b}$ & 1140 & 4.40 & 0.18 & - \\
\hline & 14 & 3-Ethyl-3-hydroxyhexanoate & $\mathrm{b}$ & 1143 & 1.51 & 0.75 & - \\
\hline & 15 & Ethyl benzoate & $\mathrm{b}$ & 1174 & 51.10 & 0.59 & - \\
\hline & 16 & Ethyl octanoate & $\mathrm{a}$ & 1198 & 383.00 & 6.08 & 5.0 \\
\hline & 17 & Phenethyl acetate & $\mathrm{b}$ & 1242 & 21.60 & 0.31 & 0.50 \\
\hline & 18 & Isopentyl hexanoate & $\mathrm{b}$ & 1249 & 4.50 & 0.29 & - \\
\hline & 19 & 2-Phenylethyl acetate & $\mathrm{b}$ & 1254 & 100.10 & 2.30 & 250.0 \\
\hline & 20 & Ethyl Decanoate & $\mathrm{b}$ & 1384 & 116.00 & 8.95 & 200.0 \\
\hline & 21 & Ethyl-3-methylbutyl butanedioate & $\mathrm{c}$ & 1427 & 21.40 & 0.55 & - \\
\hline & 22 & Diethyl succinate & $\mathrm{b}$ & 1430 & 5.80 & 0.11 & 70.0 \\
\hline & 23 & Phenylethyl lactate & $\mathrm{c}$ & 1434 & 2.90 & 0.81 & - \\
\hline & 24 & Isopentyl octanoate & $\mathrm{b}$ & 1442 & 4.20 & 5.40 & - \\
\hline & 25 & (E)-ethyl cinnamate & $\mathrm{b}$ & 1460 & 21.60 & 1.37 & 1.10 \\
\hline & 26 & Isopropyl tetradecanoate & $\mathrm{b}$ & 1781 & 1.50 & 0.79 & - \\
\hline & & Sum & & & 1934.51 & & \\
\hline & 27 & $\alpha$-Terpineol & $\mathrm{b}$ & 1190 & 19.70 & 0.31 & 330.0 \\
\hline \multirow{10}{*}{ Terpenes } & 28 & Citronellol & $\mathrm{b}$ & 1224 & 2.70 & 0.12 & - \\
\hline & 29 & Vitispirane & $\mathrm{b}$ & 1272 & 21.50 & 0.03 & - \\
\hline & 30 & B-ionone & $\mathrm{b}$ & 1308 & 10.40 & 0.18 & - \\
\hline & 31 & $\beta$-(E)-damascenone & $\mathrm{b}$ & 1379 & 1.10 & 0.03 & 0.10 \\
\hline & 32 & $\beta$-Farnesene & $\mathrm{b}$ & 1453 & 0.90 & 0.13 & - \\
\hline & 33 & $\alpha$-(Z)-bisabolene epoxide & b & 1470 & 5.30 & 0.19 & - \\
\hline & 34 & Geranyl acetone & $\mathrm{b}$ & 1449 & 24.50 & 0.27 & - \\
\hline & 35 & $\beta$-Nerolidol & $\mathrm{b}$ & 1555 & 13.40 & 0.08 & - \\
\hline & & Sum & & & 99.50 & & \\
\hline & 36 & 2-Pentanone & b & 742 & 1.90 & 0.16 & - \\
\hline \multirow{4}{*}{ Ketones } & 37 & 6-Methyl-hept-5-en-2-one & $\mathrm{b}$ & 988 & 4.90 & 1.38 & - \\
\hline & 38 & Acetophenone & $\mathrm{b}$ & 1062 & 2.80 & 0.32 & 65.0 \\
\hline & & Sum & & & 9.60 & & \\
\hline & 39 & 2-Methyl-1-butanol & a & 744 & 33.60 & 6.43 & 280.0 \\
\hline \multirow{11}{*}{ Alcohols } & 40 & 3-Methyl-1-butanol & $\mathrm{a}$ & 741 & 2434.00 & 63.67 & 280.0 \\
\hline & 41 & 3-(Z)-hexenol & $\mathrm{b}$ & 861 & 269.00 & 10.82 & 385.0 \\
\hline & 42 & 1-Hexanol & $\mathrm{a}$ & 874 & 227.00 & 12.88 & 600.0 \\
\hline & 43 & 2-Ethyl-hexan-1-ol & $\mathrm{b}$ & 1031 & 1.80 & 0.07 & 270.0 \\
\hline & 44 & 1-Octanol & $\mathrm{a}$ & 1073 & 5.10 & 0.20 & - \\
\hline & 45 & Phenylethanol & $\mathrm{a}$ & 1132 & 1059.00 & 33.29 & 1100.0 \\
\hline & 46 & 3-(Z)-nonenol & $\mathrm{b}$ & 1163 & 1.10 & 0.20 & 200.0 \\
\hline & 47 & 1-Nonanol & $\mathrm{b}$ & 1178 & 6.70 & 0.28 & - \\
\hline & 48 & 2-Undecanol & $\mathrm{b}$ & 1258 & 1.50 & 0.33 & - \\
\hline & & Sum & & & 4038.80 & & \\
\hline & 49 & Hexanoic acid & a & 991 & 1.00 & 0.48 & 3000.0 \\
\hline \multirow{3}{*}{ Acids } & 50 & Octanoic acid & $\mathrm{b}$ & 1194 & 44.80 & 6.64 & \\
\hline & 51 & Decanoic acid & $\mathrm{b}$ & 1376 & 34.50 & 3.57 & 10000.0 \\
\hline & & Sum & & & 80.30 & & \\
\hline
\end{tabular}

${ }^{a}$ Reliability of identification: a) positively identified through the use of standards; b) tentatively identified through agreement of the mass spectrum and RIexp with the literature; c) tentatively identified through agreement of the mass spectrum with the literature. ${ }^{\mathrm{b}} \mathrm{Published}$ odor threshold data (PINO \& QUERIS, 2011). 
guava wine as being within the limits established by the Brazilian legislation of $50-130$ and $<20 \mathrm{mEq} \mathrm{L}^{-1}$ for the total acidity and volatile acidity, respectively, and as having an alcoholic graduation between 10 and $13 \%$. The sugar content was calculated as $4.2 \pm 0.6 \mathrm{~g}$ $\mathrm{L}^{-1}$, which places this sparkling wine in the "extra brut" category (sparkling wines up to $6 \mathrm{~g}$ sugar $\mathrm{L}^{-1}$ are categorized as "extra brut") (BRASIL, 2004).

\section{Volatile compounds of the natural sparkling guava wine} Eighty-nine volatile compounds were detected, of which 42 were tentatively identified and 9 were positively identified by comparison with standards. Among the identified compounds, one can find 26 esters, 10 alcohols, 9 terpenes, 3 ketones, and 3 acids (Table 1). The remaining 37 unidentified volatile compounds comprised $9.42 \%$ of the total chromatogram area on average.

Esters were the predominant volatile compounds in natural sparkling guava wine sample, totaling a concentration of $1934.5 \mu \mathrm{g} \mathrm{L}^{-1}$. Compounds with the highest concentrations included ethyl octanoate $\left(383.0 \mu \mathrm{g} \mathrm{L}^{-1}\right)$, isobutyl acetate $(335.0 \mu \mathrm{g}$ $\left.\mathrm{L}^{-1}\right)$, ethyl 3(E)-hexenoate $\left(176.0 \mu \mathrm{g} \mathrm{L}^{-1}\right)$, ethyl decanoate $\left(116.0 \mu \mathrm{g} \mathrm{L}^{-1}\right)$, hexyl acetate $(106.3 \mu \mathrm{g}$ $\left.\mathrm{L}^{-1}\right)$, and 2-phenylethyl acetate $\left(100.1 \mu \mathrm{g} \mathrm{L}^{-1}\right)$. Ethyl octanoate, in this concentration range, may have contributed fruit/floral scent notes to the aroma of the beverage, as its concentration is 75 times higher than the perception threshold (TORRESI et al., 2011). This analyte can come from the matrix itself, as reported by CHEN et al. (2006), who reported a concentration of $159 \mu \mathrm{g} \mathrm{L}^{-1}$ in guava. PINO \& QUERIS (2011) reported the same compound at a concentration of $235.4 \mu \mathrm{g} \mathrm{L}^{-1}$ in fermented guava and observed a relationship with the primary fermentation. Furthermore, other identified esters are also reported in the guava matrix, such as methyl hexanoate $\left(2.78 \mu \mathrm{g} \mathrm{L} \mathrm{L}^{-1}\right)$, ethyl hexanoate $(396 \mu \mathrm{g}$ $\left.\mathrm{L}^{-1}\right)$, ethyl decanoate $\left(116 \mu \mathrm{g} \mathrm{L}^{-1}\right)$ and 2-phenylethyl acetate $\left(100 \mu \mathrm{g} \mathrm{L}^{-1}\right)$ (SCHREIER \& IDSTEIN, 1985; CHEN et al., 2006; SOARES et al., 2007). Ethyl hexanoate and (E)-ethyl cinnamate compounds present in wine samples are described as fruity, strawberry, sweet, and floral flavor compounds (AZNAR et al., 2001).

Higher alcohols presented the highest total concentration in natural sparkling guava wine

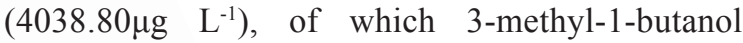
was the most abundant and may contribute to the characteristic odors of whiskey, malt, wine, banana, and sweet (SOUZA et al., 2010). This compound has already been reported in natural sparkling blackberry wine by JIANQIANG et al. (2008). Of the alcohols identified, 3-(Z)-hexenol $\left(269.0 \mu \mathrm{g} \mathrm{L}^{-1}\right)$, 1-hexanol $\left(227.0 \mu \mathrm{g} \mathrm{L}^{-1}\right), 1$-octanol $\left(5.1 \mu \mathrm{g} \mathrm{L}^{-1}\right)$ and phenylethyl alcohol have been described in guava fruit (SCHREIER \& IDSTEIN, 1985) and guava wine (PINO \& QUERIS, 2011). In the present research, phenethyl alcohol was the analyte with the second highest concentration; it had been reported as the largest odoriferous component in Finnish sherry and berry wines (NYKANEM, 1986). Higher alcohols (2- and 3-methyl-1-butanol, 1-hexanol) are compounds formed during the alcoholic fermentation process (PINO \& QUERIS, 2011) and are; therefore, characteristic of wines and fermented beverages (SOUZA, 2010). These compounds are also abundant in Brazilian "brut" sparkling wines (RIZZON et al., 2000).

The terpenes present in natural sparkling guava wine amounted to $99.5 \mu \mathrm{g} \mathrm{L}^{-1}$, with 9 different substances identified. PINO \& QUERIS (2011) reported that this class represented only $0.2 \%$ of the volatile fraction of fermented guava, with six terpenes identified, all of which are also present in the fruit matrix. Of these six compounds, only two were identified in natural sparkling guava wine: $\alpha$-terpineol and $\beta$-damascenone. The former (as well as citronellol) can be formed during yeast autolysis during the second fermentation step (TORRESI et al., 2011). The compound (E)-6,10-dimethyl-5,9undecadien-2-one, also known as geranyl acetone, is classified as a norisoprenoid derived from the degradation of long chain terpenes ( $\beta$-carotene and lycopene), conferring a floral aroma to ripe fruit (LEWINSOHN et al., 2005; CENTENO \& RUST, 2009). C13-norisoprenoids, such as vitispirane $\left(21.50 \mu \mathrm{g} \mathrm{L}^{-1}\right), \beta$-ionone $(10.40 \mu \mathrm{g} / \mathrm{L})$ and trans- $\beta$ damascenone $\left(1.10 \mu \mathrm{g} \mathrm{L}^{-1}\right)$, were identified in the sparkling wine. Formation of these compounds may be related to the degradation of pigments in the guava matrix (MERCADANTE, 1999). These compounds are known for their contribution to the aroma of fruits and their derivatives. Vitispirane can be used to differentiate between young and aged sparkling wines (TORRESI et al., 2011) (2011). $\beta$-Damascenone; although, reported in low concentrations, has a low odor threshold value $\left(0.1 \mu \mathrm{g} \mathrm{L}^{-1}\right)$ and can thus significantly influence the aroma of the product.

Only three compounds in the ketone class were identified: 6-methylhept-5-en-2-one, 2-pentanone, and acetophenone; PINO \& QUERIS (2011) identified all three in the volatile fraction of fermented guava. The 6-Methylhept-5-en-2-one 
$\left(4.90 \mu \mathrm{g} \mathrm{L}^{-1}\right)$ and acetophenone $\left(2.80 \mu \mathrm{g} \mathrm{L}^{-1}\right)$ were also reported in guava (SCHREIER \& IDSTEIN, 1985).

Three acids were quantified: hexanoic acid (1.0 $\left.\mu \mathrm{g} \mathrm{L}^{-1}\right)$, octanoic acid $\left(44.8 \mu \mathrm{g} \mathrm{L}^{-1}\right)$, and decanoic acid $\left(34.5 \mu \mathrm{g} \mathrm{L}^{-1}\right)$. Hexanoic acid (also known as capric acid) is responsible for an unpleasant, pungent, and cheese-like odor; decanoic acid is also described as unpleasant with rancid notes (MOREIRA et al., 2012). According to PINO \& QUERIS (2011), these acids have already been identified in the guava matrix, and in the present study, were above the threshold value of sensory perception (Table 1).

No aldehyde compounds were reported in the natural sparkling guava wine samples. SOARES et al. (2007) reported the abundance of aldehyde compounds in unripe guava as well as their decrease associated with an increase in esters throughout maturation process. A reduction of the aldehyde content was indicated during the aging of sparkling wine (TORRESI et al., 2011).

\section{CONCLUSION}

Natural sparkling wine that was produced presented a complex composition of fruity and floral aromas, determined by its volatile composition, in which many compounds that are likely responsible for the beverage's aroma and flavor were identified. Among the compounds of higher sensory relevance, we found ethyl octanoate, ethyl hexanoate, phenethyl acetate, $\beta$-(E)-damascenone, (E)-ethylcinnamate, 2-methylbutyl acetate, 3-methyl-1-butanol, ethyl 3-(E)-hexenoate, and methyl 5-hexenoate. Furthermore, the use of the method traditionally applied to grapes, the champenoise method, enabled the production of a natural sparkling guava wine with physicochemical characteristics equivalent to those of sparkling wines made from grapes.

\section{REFERENCES}

AMERINE, M.A.; OUGH, C.S. Methods for analysis of must and wines. New York: Wiley-Insterscience, 1980. 341p.

AZNAR, M. et al. Identification and quantification of impact odorants of aged red wines from Rioja. GC-Olfactometry, quantitative GC-MS, and odor evaluation of HPLC fractions. Journal of Agricultural and Food Chemistry, v.49, p.2924-2929, 2001. Available from: <http://pubs.acs.org/doi/pdfplus/10.1021/ jf001372u>. Accessed: Oct. 10, 2012. doi: 10.1021/jf001372u.

BERNARDI, G. et al. Jelly Palm (Butia odorata) Wine: characterization of volatile compounds responsible for aroma. Food Analytical Methods. In press. Available from: <http://link. springer.com/article/10.1007\%2Fs12161-014-9835-5\#page-1>. Accessed: July 18, 2014. doi: 10.1007/s12161-014-9835-5.
BRASIL. Ministério da Agricultura, Pecuária e Abastecimento. Altera dispositivos da Lei 7679/1088. Lei 10970 de 12 de novembro de 2004. Brazil, 2004. Diário oficial da União, 16 de novembro de 2004, p. 1.

BOSCH-FUSTÉ, J. et al. Volatile profiles of sparkling wines obtained by three extraction methods and gas chromatographymass spectrometry (GC-MS) analysis. Food Chemistry, v.105, p.428-435, 2007. Available from: <http://www.sciencedirect.com/ science/article /pii/S0308814607000398>. Accessed: July 15, 2012. doi: S0308814607000398.

CARVALHO, C.V. Espumantes de maçã obtidos pelos processos asti, charmat e champenoise. 2009. 62f. Dissertation (Graduate Program in Food Science and Technology) - Ponta Grossa State University [Universidade Estadual de Ponta Grossa].

CENTENO, D.C.; RUST, N. Contribuidores do sabor em tomate (Solanum lycopersicum var.Moneymaker) e suas inter-relações. Revista Tropica - Ciencias Agrarias e Biologicas, v.3, n.2, p.4, 2009. Available from: <http://www.periodicoseletronicos.ufma. br/index.php/ccaatropica/article/viewFile/44/29>. Accessed: Sept. 21, 2013.

CHEN, H. et al. Characterization of volatiles in Guava (Psidium guajava L. cv. 'Chung-Shan-Yueh-Pa') fruit from Taiwan. Journal of Food and Drug Analysis, v.14, n.4, p.398-402, 2006. Available from: <http://ntur.lib.ntu.edu.tw/ handle/246246/213686>. Accessed: Aug. 10, 2012. doi: 213686.

ETIEVANT, X.P., MAARSE H. Volatile compounds in foods and beverages. New York: Marcel Dekker, 1991. 784p.

JIANQIANG, S. et al. Study on the volatile compounds in the blackberry sparkling wine by GC/MS. Food and Fermentation Industries, v.8, p.51. 2008. Available from: <http://en.cnki.com. cn/Article_en/CJFDTOTAL-SPFX200808051.htm>. Accessed: Sept. 25, 2013.

LEWINSOHN, E. et al. Not just colors - carotenoid degradation as a link between pigmentation and aroma in tomato and watermelon fruit. Trends in Food Science \& Technology, v.16, p.407-415, 2005. Available from: <http://www.sciencedirect.com/science/ article/pii/S0924224405001536>. Accessed: Aug. 05, 2011. doi: S0924224405001536.

LIMA, R.K. et al. Composition of the essential oil from the leaves of tree domestic varieties and one wild variety of the guava plant (Psidium guajava L., Myrtaceae). Brazilian Journal of Pharmacognosy, v.20, n.1, p.41-44, 2010. Available from: <http://www.scielo.br/scielo.php?pid=S0102695X2010000100009\&script=sci_arttext $>$. Accessed: Apr. 10, 2011. doi: S0102-695X2010000100009.

LOPES, R.V.V.; SILVA, F.L.H. Elaboração de fermentados a partir do figo-da-india. Revista de Biologia e Ciências da Terra, v.6, n.2, p.305-315, 2006. Available from: <http://eduep.uepb.edu.br/ rbct/sumarios/pdf/palmaforrageira.pdf $>$. Accessed: Apr. 14, 2014.

MERCADANTE, A.Z. Chromatographic separation of carotenoids. Archivos Latinoamericanos de Nutricion, v.49, p.52-57, 1999. Available from: <http://www.ncbi.nlm.nih.gov/ pubmed/10971844>. Accessed: Nov. 11, 2011. doi: 10971844.

MOREIRA, R.F.A. et al. A fração volátil das aguardentes de cana produzidas no Brasil. Quimica Nova, v.35, n.9, p.1819- 
1826, 2012. Available from: <http://www.scielo.br/scielo. php script $=$ sci_arttext\&pid $=$ S0 100-40422012000900022 $>$. Accessed: Mar. 17, 2014.

NIST (NATIONAL INSTITUTE OF STANDARDS AND TECHNOLOGY'S). Available from: <http://www.nist.gov/ index.cfm>. Accessed: Dec. 12, 2012.

NYKANEN, L. Formation and occurrence of flavor compounds in wine and distilled alcoholic beverages. American Journal of Enology and Viticulture, v. 37, n. 1, p. 84-96., 1986. Available from: < http://www.ajevonline.org/content/37/1/84.abstract $>$. Accessed: Oct. 20, 2010.

El-SAYED, A.M. The pherobase: database of insect pheromones and semiochemicals, 2014. Available from: <http://www. pherobase.com/>. Accessed: July 12, 2014.

PINO, J.A.; QUERIS, O. Analysis of volatile compounds of pineapple wine using solid-phase microextraction techniques. Food Chemistry, v.122, p.1241-1246, 2010. Available from: <http:// www.sciencedirect.com/science/article/pii/S0308814610003079>. Accessed: Jan. 21, 2011.

PINO, J.A.; QUERIS, O. Characterization of odor-active compounds in guava wine. Journal of Agricultural and Food Chemistry, v.59, p.4885-4890, 2011. Available from: <http:// pubs.acs.org/doi/abs/10.1021/jf2011112\#citing >. Accessed: Nov. 11, 2011. doi: 10.1021/jf2011112.

RIZZON, L.A. et al. Elaboração de vinho espumante na propriedade vitícola. Bento Gonçalves: Embrapa: Uva e Vinho, 2000. 23p.
SANDHU, D.K.; JOSHI, V.K. Technology, quality and scope of fruit wines especially apple beverages. Indian Food Industry, v.14, n.1, p.24-34, 1995.

SCHREIER, P.; IDSTEIN, H. Volatile constituents from Guava (Psidium guajava L.) fruit. Journal of Agricultural and Food Chemistry, v.33, p.138-143, 1985. Available from: <http://pubs.acs.org/doi/abs/10.1021/ jf00061a039>. Accessed: Apr. 25, 2012. doi: 10.1021/jf00061a039.

SOARES, F.D. et al. Volatile and non-volatile chemical composition of the white guava fruit (Psidium guajava L.) at different stages of maturity. Food Chemistry, v.100, p.15-21, 2007. Available from: $<$ http://dx.doi.org/10.1016/j.foodchem.2005.07.061>. Accessed: May 10, 2011. doi: 2005.07.061.

SOUZA, A.L.C. Uso de metodologias combinadas de análise sensorial e químico-analíticas para controle de qualidade de vinhos espumantes nacionais. 2010. 77f. Dissertation (Graduate Program in Food Science) Federal University of Bahia [Universidade Federal da Bahia].

TORRESI, S. et al. Biotechnologies in sparkling wine production. Interesting approaches for quality improvement: a review. Food Chemistry, v.129, p.1232-1241, 2011. Available from: <http:// dx.doi.org/10.1016/j.foodchem. 2011.05.006>. Accessed: Apr. 25, 2012. doi: 2011.05.006.

UBIGLI, M. Guida all'assaggio degli spumanti. In: AGRICOLE (Ed.). I profili del vino. 2004. p.103-116. Available from: $<$ http://www.astilibri. com/cultura/profili_vino09.htm $>$. Accessed: May 16, 2014.

ZOECKLEIN, B.W. A review of method champenoise production. Zaragoza:Espanha. Virginia Cooperative Extension, 2002. 30p. (Publication, 463-017W). 